\title{
Isolation, Structural Elucidation and Therapeutic Potentials of Root of Cucurbita pepo
}

\author{
PA. EKEOCHA, CO. EZEH, JV. ANYAM ${ }^{1}$, KC. ONYEKWELU ${ }^{1 *}$, J. IKEKPEAZU AND JO. IGOLI ${ }^{1}$ \\ Department of Medical Biochemistry, College of Medicine, University of Nigeria, Enugu Campus, Enugu 400001, ${ }^{1}$ Department \\ of Chemistry, Joseph Sarwuan Tarka University, Makurdi 970101, Nigeria
}

\section{Ekeocha et al.: Spinasterol from the Roots of Cucurbita Pepo}

\begin{abstract}
The roots of Cucurbita pepo were investigated with the aim of identifying bioactive constituents with therapeutic potentials. To achieve this, the roots of Cucurbita pepo were harvested, washed, air dried and grounded into the powder. The ground material was extracted using hexane, ethyl acetate and methanol. The extracts were fractionated using column chromatography and fractions were monitored using thin layer chromatography. The fractions were characterised using proton nuclear magnetic resonance and carbon-13 nuclear magnetic resonance spectroscopy. Phytochemical screening showed that the extracts contained sterols and terpenoids, alkaloids, resins, flavonoids, saponins and carbohydrates. Nuclear magnetic resonance analysis led to the identification of hexadecanoic acid or palmitic acid, alphaspinasterol and squalene. Some of these compounds may represent a new pharmacological approach in the development of novel and adjuvant therapy for several medical conditions.
\end{abstract}

Key words: Hexadecanoic acid, alpha-spinasterol, squalene, Cucurbita pepo, nuclear magnetic resonance spectroscopy

Plants are rich in bioactive compounds that have various medicinal properties ${ }^{[1-3]}$. Developments in technology have made it possible to identify and purify these secondary metabolites which have served as the backbone in the formulation of many pharmaceutical drugs ${ }^{[4]}$. In addition to the various side effects and limited efficacy of orthodox drugs, there is an increase in the development of resistance by disease causing organisms to orthodox drugs with the tendency of the disease to reoccur ${ }^{[5]}$. This has led to a growing interest in the search for alternative therapeutic drugs derived from plants.

Phytochemical studies are driven by the need for the discovery of inexpensive, safer and new drugs which is performed by screening different parts (root, leave, stem and seed) of local medicinal plants in order to develop drugs to combat various health challenges faced by $\operatorname{man}^{[6]}$. Pumpkin belongs to the family Cucubitaceae and is comprised of Cucurbita moschata, Cucurbita pepo, Cucurbita maxima, Cucurbita mixta, Cucurbita ficifolia and Telfairia occidentalis. The economically important species cultivated worldwide are Cucurbita pepo, Cucurbita maxima and Cucurbita moschata ${ }^{[7,8]}$. The use of pumpkin in various traditional medicines for the treatment of several ailments has attracted scientific

*Address for correspondence

E-mail: kenechukwu.onyekwelu@unn.edu.ng

November-December 2021 attention to this plant ${ }^{[9]}$. Pumpkin contains biologically active components that include polysaccharides, para-aminobenzoic acid, fixed oils, sterol, proteins and peptides ${ }^{[10]}$. While the fruits are a good source of carotenoid and gamma-aminobutyric acid ${ }^{[11,12]}$, the presence of anti-nutrients in pumpkin seeds have limited the usefulness of fresh pumpkin seed as a protein source for human food ${ }^{[13-15]}$. Phytochemicals such as polysaccharides, phenolic glycosides, 13-hydroxy9Z, 11E-octadecatrienoic acid from the leaves of pumpkin and proteins from germinated seeds have been isolated $^{[16-18]}$.

The upsurge in techniques involved in the isolation and identification of novel natural compounds from plant materials have made the discovery of novel compounds which have the potential to become drugs more feasible. Isolation of bioactive compounds from different parts of plants is performed using chromatographic

\footnotetext{
This is an open access article distributed under the terms of the Creative Commons Attribution-NonCommercial-ShareAlike 3.0 License, which allows others to remix, tweak, and build upon the work non-commercially, as long as the author is credited and the new creations are licensed under the identical terms
}

Accepted 07 December 2021 
techniques such as Thin Layer Chromatography (TLC), Preparative Thin Layer Chromatography (PTLC), Column Chromatography (CC), Medium Pressure Liquid Chromatography (MPLC) and High Performance Liquid Chromatography (HPLC) amongst others ${ }^{[19]}$. Structure elucidation provides the molecular structures of compounds through the use of techniques such as Nuclear Magnetic Resonance (NMR) and Mass Spectrometry (MS) analysis ${ }^{[20]}$.

This study focused on the roots of Cucurbita pepo (pumpkin). Ethno-medicinal reports indicate the traditional use of different parts of the plant (seed, fruit, vegetative part) in the treatment of different health problems and as functional food ${ }^{[21-24]}$ but no work has been carried out on the roots. There is a growing interest in determining the scientific basis for the usage of plants in primary health care and in discovering novel compounds of pharmaceutical importance ${ }^{[25]}$. In this study, column chromatography was used to isolate some bioactive compounds and NMR used to identify the isolated compounds from the roots of Cucurbita pepo.

\section{MATERIALS AND METHODS}

\section{Collection of plant material:}

The roots of Cucurbita pepo were collected from a farm within the University of Nigeria, Nsukka. The plant was authenticated by a taxonomist in the Department of Plant Sciences and Biotechnology, of the University and a voucher specimen was deposited at the herbarium as UNH no. 552. The roots were washed and air dried. Once completely dry, the roots were ground to powder using a blender. The ground roots were stored in closed containers at room temperature until required.

\section{Extraction and phytochemical screening:}

The powdered material $(350 \mathrm{~g})$ was introduced into a Winchester bottle and macerated successively for 48 h with $700 \mathrm{ml}$ of hexane, ethyl acetate and methanol. The extracts were filtered into clean glass jars using Whatman No.1 filter papers and allowed to dry in fume hood. All extracts were subjected to phytochemical tests using the procedure outlined by Trease et al. ${ }^{[26]}$ to detect the presence of secondary metabolites. Test for the presence of carbohydrates, alkaloids, glycosides, saponins, flavonoids, resins, steroids terpenoids, reducing sugars and tannins were carried out.

\section{Column chromatography of the ethyl acetate extract:}

The ethyl acetate extract was fractionated using column chromatography as described by Hostettmann et al. ${ }^{[27]}$. The extract was adsorbed onto silica gel and dried until a free flowing powder was obtained. It was then loaded onto a column packed with $150 \mathrm{~g}$ silica gel. The column was eluted gradient wise with increasing amounts of ethyl acetate in hexane until $100 \%$ ethyl acetate. Column fractions were monitored using thin layer chromatography and further purified by repeated CC. Similar fractions were combined on the basis of TLC and allowed to dry.

\section{NMR spectroscopy:}

The ${ }^{1} \mathrm{H}$ and ${ }^{13} \mathrm{C}$ NMR spectra were acquired using a Bruker DPX $400 \mathrm{MH}_{\mathrm{Z}}$ spectrophotometer. Deuterated chloroform $\left(\mathrm{CDCl}_{3}\right)$ was used as solvent while Tetramethylsilane (TMS) was used as internal standard. Spectra were processed using MestReNova (Mestrelab Research S.L., Santiago de Compostela, Spain) Software.

\section{RESULTS AND DISCUSSION}

Phytochemical screening of extracts showed that the root extracts of Cucurbita pepo contained sterols and terpenoids, alkaloids, resins, flavonoids, saponins and carbohydrates. NMR analysis led to the identification of the below mentioned compounds.

White crystalline solid characterized as follows: ${ }^{1} \mathrm{HNMR}\left(400 \mathrm{MHz} ; \mathrm{CDCl}_{3}\right): 2.32(2 \mathrm{H}, \mathrm{t}, \mathrm{J}=7.3 \mathrm{~Hz}$, $\mathrm{H}-2), 1.60$ (2H, m, H-3), 1.28 (2H, m, H-15), 1.26 (22H, br, s, H-4 to H-14), 0.89 (3H, t, J=7.3 Hz, H-16).

${ }^{13} \mathrm{C}-\mathrm{NMR}\left(100 \mathrm{MHz}, \mathrm{CDCl}_{3}\right): 178.3$ (C-1), 33.0 (C-2), 31.8 (C-14), 29.0-29.7 (C-4) to C-13); 24.6 (C-3), 21.6 (C-15), 14.0 (C-16) (Table 1).

The identity of this compound was confirmed to be hexadecanoic acid or palmitic acid (fig. 1). The ${ }^{1} \mathrm{HNMR}$ spectrum showed the features of an aliphatic carboxylic acid at region between $\delta^{\mathrm{H}} 0.81-2.41$. The spectrum

TABLE 1: ${ }^{1} \mathrm{H}$ NMR, ${ }^{13} \mathrm{C}$ NMR CHEMICAL SHIFTS OF HEXADECANOIC ACID (400 MHz, CDCL $\left.)_{3}\right)$

\begin{tabular}{cccc}
\hline Position & $13 \mathrm{C}(\boldsymbol{\delta})$ & $\mathrm{H}(\boldsymbol{\delta})$ & $\mathrm{HMBC}$ \\
\hline 1 & 178.3 & - & - \\
2 & 34 & $2.32(\mathrm{t}, \mathrm{J}=7.3 \mathrm{~Hz})$ & $\mathrm{C}-1, \mathrm{C}-3, \mathrm{C}-4$ \\
3 & 24.7 & $1.60, \mathrm{~m}$ & $\mathrm{C}-1, \mathrm{C}-2, \mathrm{C}-4$ \\
$4-13$ & $29.0-29.5$ & $1.26, \mathrm{br} \mathrm{s}$ & - \\
14 & 31.9 & - & $\mathrm{C}-15$ \\
15 & 22.7 & $1.28, \mathrm{~m}$ & $\mathrm{C}-13, \mathrm{C}-14, \mathrm{C}-16$ \\
16 & 14.1 & $0.89(\mathrm{t}, \mathrm{J}=7.3 \mathrm{~Hz})$ & $\mathrm{C}-14, \mathrm{C}-15$ \\
\hline
\end{tabular}


showed the presence of a set of long chain methylene protons representing 11 methylene groups overlapped as a broad peak at $1.25 \mathrm{ppm}$. The ${ }^{13} \mathrm{C}$ NMR spectrum showed seven signals including a carbonyl signal at $\delta^{\mathrm{C}} 178.30$, a terminal methyl $(\mathrm{C}-16)$ at $\delta^{\mathrm{C}} 14.1$ and methylene carbons (C-4 to C-13) overlapped between 29.0-29.5 ppm (fig. 2).

The ${ }^{1} \mathrm{H}$ spectrum (fig. 3) was typical of a pentacyclic triterpene and similar to stigmasterol. It showed three multiplets; one at $\delta^{\mathrm{H}} 5.18$ (typical of an olefinic H-5 or H-7 observed for steroids) and two others at 5.35 and 5.04 for protons $\mathrm{H}-22$ and $\mathrm{H}-23$ respectively. The spectrum also showed two methyl doublets at 0.81 and 0.84 for an isopropyl unit in the steroid. Two other methyl groups were observed at 0.55 and 1.08 and were assigned to tertiary methyl groups at C-18 and C-19, while the rest of the methyl signals were assigned to $\mathrm{C}-21$ and C-29. The ${ }^{13} \mathrm{C}-\mathrm{NMR}$ spectrum indicated resonances for twenty nine carbons including a carbonyl, six methyl, four olefinic and seven quaternary carbons. These signals and comparison with literature reports allowed for the identification of the steroid as spinasterol ${ }^{[28]}$ (fig. 4).

${ }^{1} \mathrm{H}$ NMR (400 $\left.\mathrm{MH}_{\mathrm{Z}}, \mathrm{CDCl}_{3}\right), \delta^{\mathrm{H}} 0.55,0.80,0.81,0.81$, $0.84,1.08,1.20,1.20,1.20,1.26,1.30,1.32,1.39,1.40$,

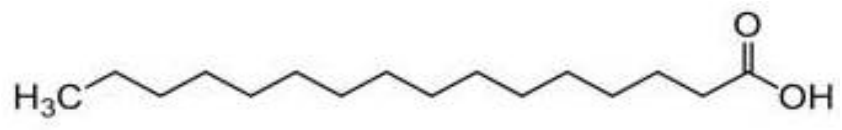

Fig. 1: Structure of hexadecanoic acid
$1.50,1.53,1.77,1.84,2.02,2.02,3.53,4.96,5.08,5.11$, 33.91 .

${ }^{13} \mathrm{C} \mathrm{NMR}\left(100 \mathrm{MH}_{\mathrm{Z}} \mathrm{CDCl}_{3}\right)$ 139.57, 138.16, 129.45, 117.46, 71.45, 55.92, 55.14, 51.25, 49.46, 43.3, 40.8, $40.28,40.28,39.47,38.00,37.15,33.91,31.9,31.48$, $29.70,28.50,25.40,23.02,21.56,21.38,21.1,19.00$, $13.05,12.2,12.06$ (Table 2).

The ${ }^{1} \mathrm{H}$ NMR Spectrum indicated resonances for three olefinic protons at $\delta^{\mathrm{H}} 5.03(1 \mathrm{H}, \mathrm{dd}, \mathrm{J}=8.6,15.2 \mathrm{~Hz}$, $\mathrm{H}-23), 5.15$. (1H br, s, H-7), 5.16 (1H, dd, J=9.0, 15.5 $\mathrm{Hz}, \mathrm{H}-22) ; 3.60$ (1H, M, H-3) and six methyl protons at $\delta^{\mathrm{H}} 0.55(3 \mathrm{H}, \mathrm{s}, \mathrm{H}-18), 0.79(3 \mathrm{H}, \mathrm{s}, \mathrm{H}-19), 0.81(3 \mathrm{H}$, t, J=7.0 Hz, H-29), 0.83 (3H, d, J=6.0 Hz, H-27), 0.85, $(3 \mathrm{H}, \mathrm{d}, \mathrm{J}=6.0 \mathrm{~Hz}, \mathrm{H}-26), 1.03$ (3H, d, J=6.0 Hz, H-21).

The ${ }^{1} \mathrm{H}$ NMR showed methyl groups at $\delta^{\mathrm{H}} 1.57(18 \mathrm{H}$, s) and $1.65(6 \mathrm{H}, \mathrm{s})$, methylene groups at 1.97-2.07 (20 $\mathrm{H}, \mathrm{m})$ and vinylic signals between 5.05-5.14 $(\mathrm{m}, 6 \mathrm{H})$. The ${ }^{13} \mathrm{C}$ NMR showed eight methylene carbons at $\delta^{\mathrm{C}}$ 16.0-25.7, ten methylene carbons between 26.69-39.75 and 12 olefinic carbons between 124.3-134.9 ppm. The protons spectrum (fig. 5) and chemical shift assignments (Table 3) are in agreement with literature reports and identified the compound as squalene (fig. 6).

${ }^{1} \mathrm{HNMR}\left(400 \mathrm{MHz} \mathrm{CDCl}_{3}\right) ; \delta 5.05-5.14(6 \mathrm{H},=\mathrm{CH}-)$, $1.57\left(18 \mathrm{H}\right.$, allylic $\mathrm{CH}_{3}$, Cis), $1.65\left(6 \mathrm{H}\right.$, allylic $\mathrm{CH}_{3}$ trans), 1.97-2.07 $\left(20 \mathrm{H}\right.$, allylic $\left.\mathrm{CH}_{3}\right) .{ }^{13} \mathrm{CNMR}(100$ $\mathrm{MHz}-\mathrm{CDCl}_{3}$ ) $\delta 25.70$ (C-1), 131.8 (C-2), 124.32 (C3), 26.73 (C-4), 39.76 (C-5), 134.88 (C-6), 124.28 (C-

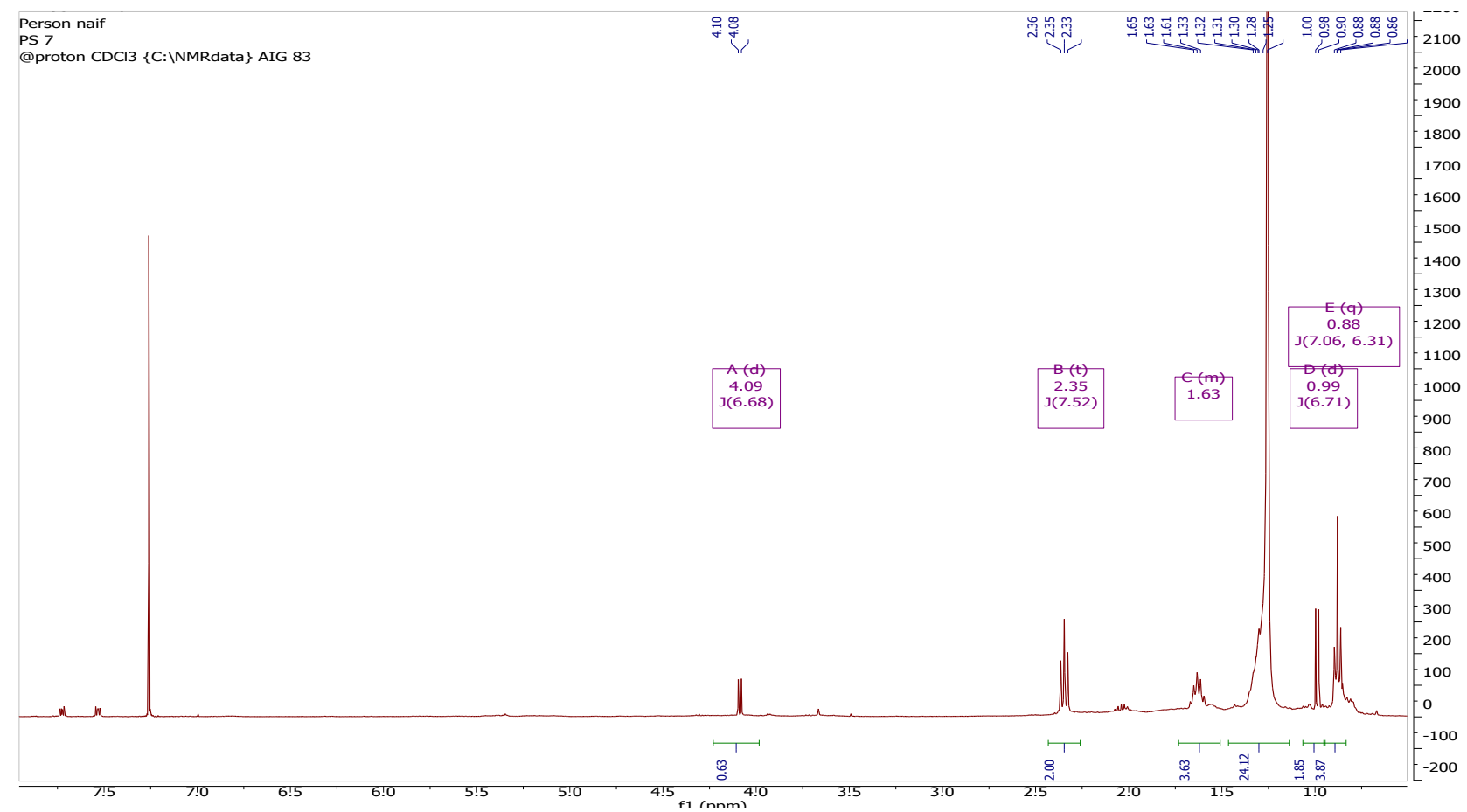

Fig. 2: Proton NMR spectrum of hexadecanoic acid 


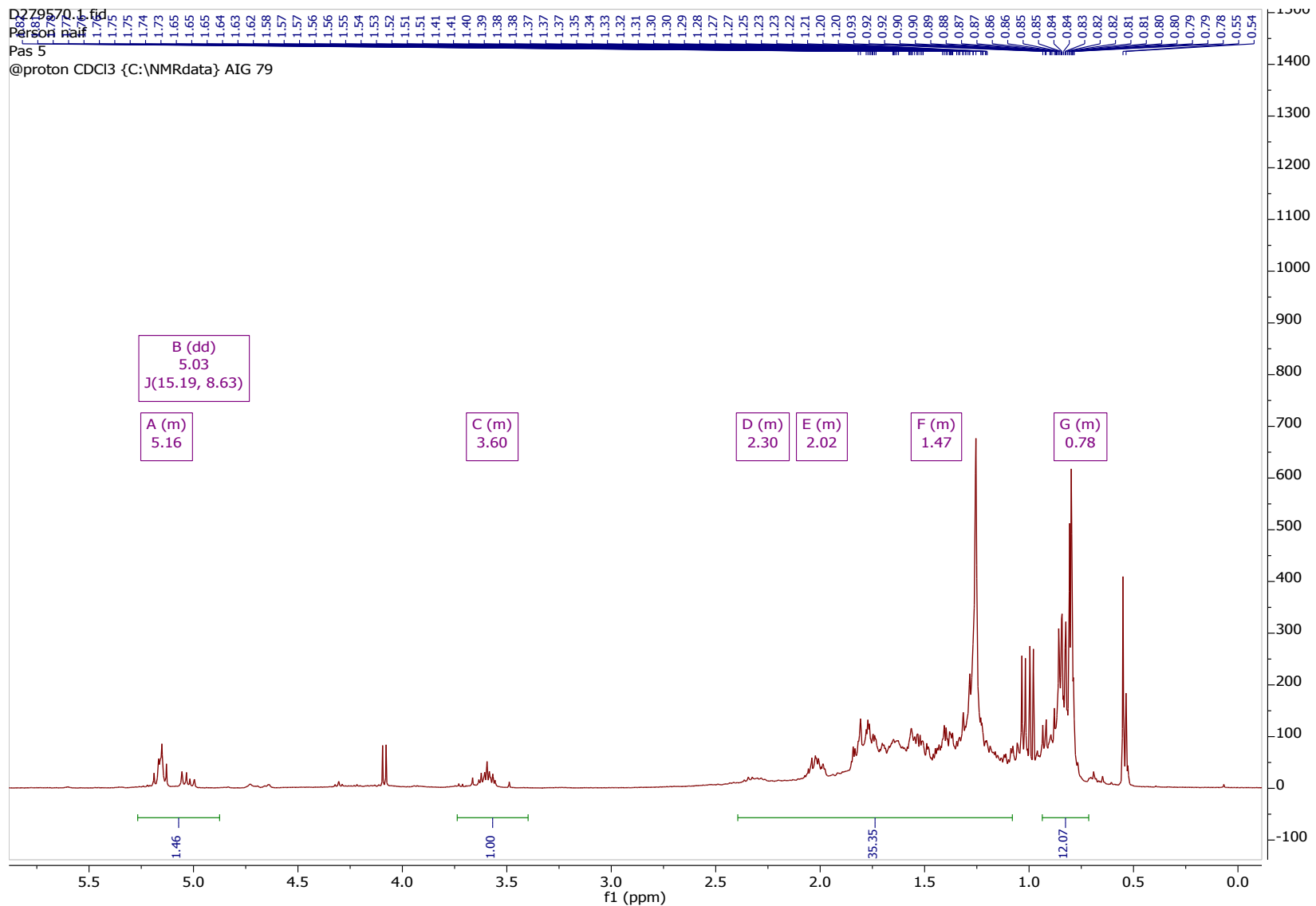

Fig. 3: NMR spectrum showing the presence of $\alpha$-spinasterol based on evaluation of its integral areas

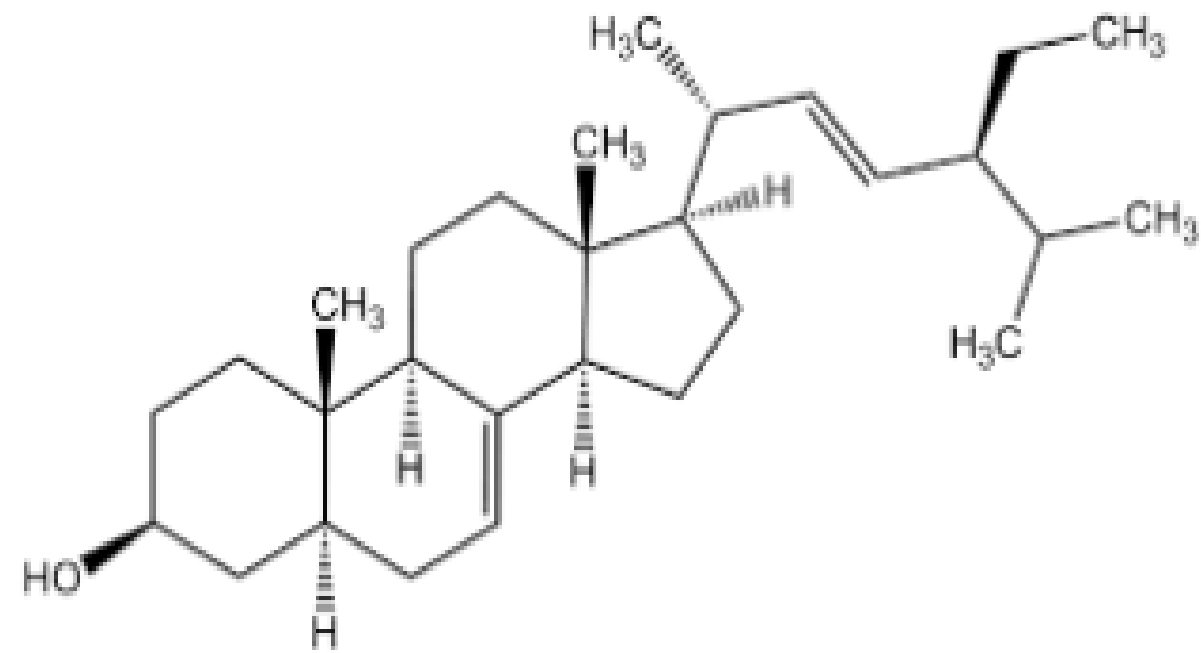

Fig. 4: Structure of spinasterol

7), 26.69 (C-8), 39.75 (C-9), 135.01 (C-10) ,124.31

(C-11), 28.28 (C-12), 17.68 (C-2), 16.03 (C-6), 16.01

(C-10) (Table 3).

Extracts of root of Cucurbita pepo showed the presence of Alpha $(\alpha)$-spinasterol which has been reported to have therapeutic effects. Studies conducted by Socała et al. ${ }^{[29,30]}$ revealed significant anticonvulsant effect of $\alpha$-spinasterol and reduced depressive-like behaviour in mice while the study carried out by Jeong et al. ${ }^{[31]}$ on $\alpha$-spinasterol isolated from the roots of Phytolacca americana suggest that $\alpha$-spinasterol has a significant therapeutic potential to modulate the development and progression of diabeticnephropathy.Apart from reducing cell infiltration in the injured tissue, oral administration of $\alpha$-spinasterol also reduces postoperative pain when administered before incision or after incision ${ }^{[32]}$. It also has anti-inflammatory activity in vivo and inhibits benign prostatic hyperplasia in rats ${ }^{[33,34]}$. 


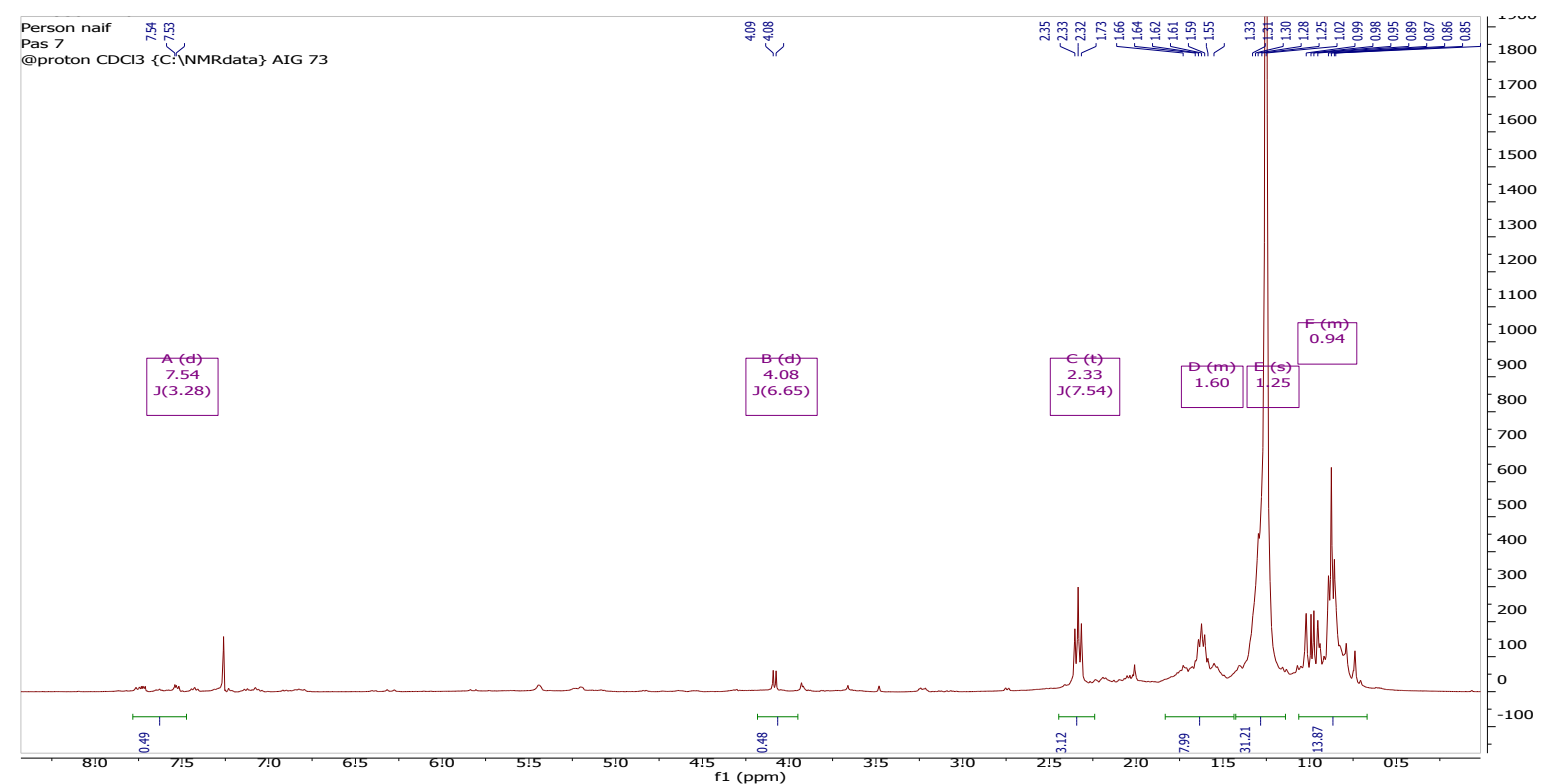

Fig. 5: Proton NMR spectrum of squalene

TABLE 2: ${ }^{13} \mathrm{C}$ NMR CHEMICAL SHIFT VALUES OF A-SPINASTEROL (100 MHz, CDCL $\mathrm{ML}_{3}$ )

\begin{tabular}{|c|c|c|}
\hline Position & Chemical shift (ס) & Type of Carbon \\
\hline 1 & 37.2 & $\mathrm{CH} 2$ \\
\hline 2 & 31.5 & \\
\hline 3 & 71.5 & \\
\hline 4 & 38 & \\
\hline 5 & 40.3 & \\
\hline 6 & 29.7 & \\
\hline 7 & 117.5 & $\mathrm{CH}$ (unsaturated) \\
\hline 8 & 139.6 & \\
\hline 9 & 49.5 & \\
\hline 10 & 34.2 & \\
\hline 11 & 21.6 & \\
\hline 12 & 39.6 & \\
\hline 13 & 43.3 & \\
\hline 14 & 55.1 & \\
\hline 15 & 23 & \\
\hline 16 & 28.5 & \\
\hline 17 & 55.9 & \\
\hline 18 & 12 & C (unsaturated) \\
\hline 19 & 13 & \\
\hline 20 & 40.8 & \\
\hline 21 & 21.4 & \\
\hline 22 & 138.1 & $\mathrm{CH}$ (unsaturated) \\
\hline 23 & 129.5 & \\
\hline 24 & 51.2 & $\mathrm{CH}$ (unsaturated) \\
\hline 25 & 31.9 & \\
\hline 26 & 21.1 & \\
\hline 27 & 19 & \\
\hline 28 & 25.4 & \\
\hline 29 & 12.2 & \\
\hline
\end{tabular}

TABLE 3: ${ }^{13} \mathrm{C}$ NMR CHEMICAL SHIFTS VALUES OF SQUALENE

\begin{tabular}{lc}
\hline $\mathbf{C}$ & ${ }^{13} \mathbf{C}(\boldsymbol{\delta})$ \\
\hline 1 & 25.70 \\
2 & 131.28 \\
3 & 124.32 \\
4 & 26.73 \\
5 & 39.76 \\
6 & 134.88 \\
7 & 124.28 \\
8 & 26.69 \\
9 & 39.75 \\
10 & 135.01 \\
11 & 124.31 \\
12 & 28.28 \\
13 & 17.68 \\
14 & 16.03 \\
15 & 16.01
\end{tabular}

Extracts of root of Cucurbita pepo also showed the presence of squalene, a terpene produced in plants which have been reported to have positive effects in the treatment of certain kinds of cancer. Examination of the seeds of Cucurbita pepo showed that it has high concentration of squalene ${ }^{[35]}$. The seeds oil of Cucurbita pepo is rich in phytosterols, fatty acids, squalene, tocopherols and other healthy components. These components make it as alternative medicine for management of men's health problem and have beneficial effects on benign prostatic hyperplasia, overactive bladder and androgenic alopecia ${ }^{[36]}$. 
www.ijpsonline.com<smiles>CC(C)=CCC/C(C)=C/CC/C(C)=C/CC/C=C(\C)CC/C=C(\C)CCC=C(C)C</smiles>

Fig. 6: Structure of squalene

Extracts of root of Cucurbita pepo showed the presence of palmitic acid. Palmitic acid is a fatty acid that is found naturally in animals and plants which is widely used in a variety of applications including personal care products and cosmetics. The Cucurbita pepo seed oil has been shown to contain palmitic acid in addition to other fatty acids such as oleic, linoleic and stearic acids ${ }^{[37]}$. Studies carried out by Mulugeta et al. ${ }^{[38]}$ and Bulama et al. ${ }^{[39]}$ on palmitic acid isolated from root wood of Moringa stenopetala and Terminalia glaucescens respectively revealed that palmitic acid has antibacterial activity which justify the use of the plants in the treatment of different bacterial infections traditionally ${ }^{[40,41]}$.

The present phytochemical investigation of root of Cucurbita pepo revealed the presence of hexadecanoic acid, $\alpha$-spinasterol and squalene. This is an initial report of these compounds from the root of this plant material.

\section{Conflict of interest:}

The authors declare no conflict of interest.

\section{REFERENCES}

1. Udeani TK, Ufelle SA, Onyekwelu KC, Onyia V, Ezechukwu IN, Ezeh RC. Effects of methanol extract of Morinda lucida leaves in Staphylococcus aureus induced infection in albino rats. Int J Pharm Sci Rev Res 2019;56(1):1-5.

2. Ufelle SA, Onyekwelu KC, Achukwu PU, Ezeh CO, Ghasi S. Haematological effects of leaf extract of Moringa oleifera Lam in normal and myelo-suppressed wistar rats. Afr J Biomed Res 2018;21(1):87-90.

3. Nwakaego NL, Chibuike OK, Chukwugekwu EM, Marylyn AC, Ngozi EI, Chukwunonye ER. In vitro antioxidant and free radical scavenging potential of methanolic extracts of Uvaria chamae leaves and roots. Int J Pharm Pharm Sci 2019;11(1):67-71.

4. Chavan SS, Damale MG, Shamkuwar PB, Pawar DP. Traditional medicinal plants for anticancer activity. Int J Curr Pharm Res 2013;5(4):50-4.

5. Nguedia AJC, Shey ND. African medicinal plant derived products as therapeutic arsenals against multidrug resistant microorganisms. J Pharmacogn Phytother 2014;6(5):59-69.

6. Webster D, Taschereau P, Belland RJ, Sand C, Rennie RP. Antifungal activity of medicinal plant extracts; preliminary screening studies. J Ethno Pharmacol 2008;115(1):140-6.

7. Robinson RW, Decker-Walters DS. Cucurbits. New York: CAB International; 1997.

8. Taylor MJ, Brant J. Trends in world cucurbit production, 1991 to 2001. In: Maynard DN (ed), Cucurbitaceae. Alexandria, VA: ASHS Press; 2002. p. 373-9.

9. Caili FU, Huan S, Quanhong LI. A review on pharmacological activities and utilization technologies of pumpkin. Plant Foods
Hum Nutr 2006;61(2):70-7.

10. Kuhlmann H, Koetter U, Theurer C. Sterol contents in medicinal pumpkin (Cucurbita pepo convar. citrullinina var. styriaca) depending on genotype and location. Acta Hortic 492:175-8.

11. Murkovic M, Mülleder U, Neunteufl H. Carotenoid content in different varieties of pumpkins. J Food Composit Analysis 2002;15(6):633-8.

12. Zhang H. Determination of $\gamma$-amino-butyric acid and amino acids in pumpkin. Food Res Dev 2003;24(3):108-9.

13. Akwaowo EU, Ndon BA, Etuk EU. Minerals and antinutrients in fluted pumpkin (Telfairia occidentalis Hook f.). Food Chem 2000;70(2):235-40.

14. Achinewhu SC, Isichei MO. The nutritional evaluation of fermented fluted pumpkin seeds (Teleferia occidentalis Hook). Discov Innov 1990;2(3):62-5.

15. Nwokolo E, Sim JS. Nutritional assessment of defatted oil meals of melon (Colocynthis citrullus L.) and fluted pumpkin (Telfaria occidentalis Hook) by chick assay. J Sci Food Agri 1987;38(3):237-46.

16. Koike K, Li W, Liu L, Hata E, Nikaido T. New phenolic glycosides from the seeds of Cucurbita moschata. Chem Pharm Bull 2005;53(2):225-8.

17. Jun HI, Lee CH, Song GS, Kim YS. Characterization of the pectic polysaccharides from pumpkin peel. Food Sci Tech 2006;39(5):554-61.

18. Quanhong L, Caili F. Application of response surface methodology for extraction optimization of germinant pumpkin seeds protein. Food Chem 2005;92(4):701-6.

19. Ley SV, Baxendale IR. New tools and concepts for modern organic synthesis. Nat Rev Drug Discov 2002;1(8):573-86.

20. Koehn FE, Carter GT. The evolving role of natural products in drug discovery. Nat Rev Drug Discov 2005;4(3):206-20.

21. Yang BM, Yang ST, Chen SN. A preliminary study on the cultivating technique of Cucurbita pepo cv Dayangua. Spec Econ Amin Plant 2000;3:28-34.

22. Kessler OJ, Keisari Y, Servadio C, Abramovici A. Role of chronic inflammation in the promotion of prostatic hyperplasia in rats. J Urol 1998;159(3):1049-53.

23. Lim TK. Edible medicinal and non-medicinal plants: Volume 2, Fruits. Springer Netherlands; 2012.

24. Choma IM, Grzelak EM. Bioautography detection in thin-layer chromatography. J Chromatogr A. 2011;1218(19):2684-91.

25. Jager AK, Hutchings A, van Staden J. Screening of Zulu medicinal plants for prostaglandin synthesis inhibitors. J Ethno Pharmacol 1996;52(2):95-100.

26. Trease GE, Evans WC. A textbook of pharmacognosy. 13th ed. Bailliere Tindall Ltd., London; 1989. p. 19-21.

27. Hostettmann K, Marston A, Hostettmann M. Preparation Chromotography in the rapid screening and isolation of bioactive compounds from medicinal plants. J Planar Chromatography 1998;10:251-7.

28. Ragasa CY, Lim K. Sterols from Cucurbita maxima. Philipp J Sci 2005;134(2):83-7.

29. Socała K, Nieoczym D, Pieróg M, Wlaź P. $\alpha$-Spinasterol, a TRPV1 receptor antagonist, elevates the seizure threshold in three acute seizure tests in mice. $\mathrm{J}$ Neural Transm 
2015;122(9):1239-47.

30. Socała K, Wlaź P. Evaluation of the antidepressant-and anxiolytic-like activity of $\alpha$-spinasterol, a plant derivative with TRPV1 antagonistic effects, in mice. Behav Brain Res 2016;303:19-25.

31. Jeong SI, Kim KJ, Choi MK, Keum KS, Lee S, Ahn SH, et al. $\alpha$-Spinasterol isolated from the root of Phytolacca americana and its pharmacological property on diabetic nephropathy. Planta Med 2004;70(8):736-9.

32. Brusco I, Camponogara C, Carvalho FB, Schetinger MRC, Oliveira MS, Trevisan G. $\alpha$-Spinasterol: a COX inhibitor and a transient receptor potential vanilloid 1 antagonist presents an antinociceptive effect in clinically relevant models of pain in mice. Br J Pharmacol 2017;174:4247-62.

33. Borges FR, Silva MD, Córdova MM, Schambach TR, Pizzolatti MG, Santos AR. Anti-inflammatory action of hydroalcoholic extract, dichloromethane fraction and steroid $\alpha$-spinasterol from Polygala sabulosa in LPS-induced peritonitis in mice. $\mathrm{J}$ Ethnopharmacol 2014;151(1):144-50.

34. Lee MY, Shin IS, Kyoung H, Seo CS, Son JK, Shin HK. $\alpha$-spinasterol from Melandrium firmum attenuates benign prostatic hyperplasia in a rat model. Mol Med Rep 2014;9(6):2362-6.

35. Martha R, Gutierrez P. Medicinal chemistry review of Cucurbitapepo (Pumpkin) its phytochemistry and pharmacology. Med Chem 2016;6(1):12-21.

36. Ramak P, Mahboubi M. The beneficial effects of pumpkin (Cucurbitapepo L.) seed oil for health condition of men. Food Rev Int 2018;35(2):166-76.

37. Badr SEA, Shaaban M, Elkholy YM, Helal MH, Hamza AS, Masoud MS. Chemical composition and biological activity of ripe pumpkin fruits (Cucurbitapepo L.) cultivated in Egyptian habitats. Nat Prod Res 2011;25(16):1524-39.

38. Mulugeta T, Legesse A, Yinebeb T, Diriba M, Shiferaw D. Isolation of compounds from acetone extract of root wood of Moringa stenopetala and evaluation of their antibacterial activities. Res J Med Plant 2013;7:32-47.

39. Bulama JS, Dangoggo SM, Halilu ME, Tsafe AI, Hassan SW. Isolation and characterization of palmitic acid from ethyl acetate extract of root bark of Terminalia Glaucescens. Chem Mat Res 2014;6(12):140-3.

40. Centre for the Evaluation of Risks to Human Reproduction (US). NTP-CERHR Monograph on the Potential Human Reproductive and Developmental Effects of Di-isononyl Phthalate (DINP). National Toxicology Program, US Department of Health and Human Services, Center for the Evaluation of Risks to Human Reproduction; 2003.

41. Toxicity review of di-n-octyl phthalate (DnOP). U.S. Consumer Products Safety Commission; 2010. 